\title{
COMPETITIVENESS FACTORS IN THE INNOVATIVE ENTERPRISES
}

\author{
Kamil DECYK (10) \\ Department of Enterprise Economics, Faculty of Economic Science, \\ University of Warmia and Mazury Oczapowskiego Street 4, 10-719 Olsztyn, Poland \\ "E-mail: kamil.decyk@uwm.edu.pl
}

\begin{abstract}
The research problem was to determine the relationship between having an action plan related to innovations by innovative enterprises and the type and degree of these enterprises' use of competitiveness factors. The objective of the research was to identify and assess competitiveness factors in innovative enterprises taking into consideration their strategic plans related to innovation management. For achieving this objective, the following research methods were used: analysis of national and foreign literature resources, survey measurement (observation technique), direct and indirect interview, research tool: questionnaire. The results were analyzed with statistical methods such as arithmetic mean, Mann-Whitney U test, Chi-square test $\left(\chi^{2}\right)$, and measures of the association including Pearson's contingency coefficient and Cramér's V coefficient were applied.

The analysis of the results showed that the assessment of competitiveness factors such as innovativeness, quality, marketing and logistics activities differed with statistical significance depending on whether the firm had a long-term action plan related to innovations. The research also showed a relationship between competing using innovativeness and having an action plan related to innovations. However, this relationship was not statistically significant. As a result, the research hypothesis can be neither rejected nor confirmed.

The conducted research proves that it is worth for innovative enterprises to develop long-term action plans related to innovations. Such enterprises boast a higher degree of utilization of competitiveness factors, which in effect may determine their strength and competitive position.

It is also needed to mention that presented in the study results are only a part of the bigger one, concerning the level of innovative activity of innovative enterprises. At the same time, the research material presented in this article does not have a statistical character and cannot be the basis for the formulation of general conclusions. However, it may be the point of reference in in-depth research on these issues.
\end{abstract}

Keywords: competitiveness, competitiveness factors, innovativeness, innovative company, innovation management.

JEL Classification: O31, O32.

Conference topic: Contemporary Organizations Development Management.

\section{Introduction}

The presented issues combine, on the one hand, aspects related to competitiveness, its economic dimension in the form of factors (instruments, determinants, conditions) ${ }^{1}$ of competitiveness. On the other hand, it refers to the sector of economic entities defined as innovative, which points to the broadly understood innovativeness at the microeconomic level. In this respect, the article also refers in part to the management field. Considering the aspect of having a longterm innovation action plan by the company is an element related to the strategic dimension of business management.

In the context of the presented issue, which is the subject of the study, the first part focuses on clarifying basic definitions, which are the basis of the methodological assumptions and are fundamental for empirical analyses. The issue of innovativeness does not have a clear definition, but the approach used in the study will be the one that recognizes it as an attribute of an enterprise (just as competitiveness) and defines it as the capability to create something new or implementing significant changes (innovations) or acting in a way that uses this capability. At the same time, it is

\footnotetext{
Bearing in mind the existence of differences in terms such as factor, tool/instrument, determinant and condition, the above terms will be used interchangeably. The terms condition and factor can be used interchangeably because they do not have a significant empirical significance due to activities being multifactorial sets, so their complexity is large, and the impact of all elements on the processes and the reactions occurring between them is generally taken into account. According to the Stownik... (1980), every factor whose function is to determine something is to be taken as a determinant, so it is also reasonable to use the two terms interchangeably.
} 
indicated that innovation is measurable and subject to assessment (Hilami, Ramayah, Mustapha, \& Pawanchik, 2010). Its notable effect is the mentioned innovation, which in a broad sense is interpreted by the Oslo Manual... (2005) as the implementation of a new or significantly improved product (or service) or process, a new marketing method or a new organizational method in business practice, organization or relations with the environment. The narrow approach. However, includes only technological aspects, i.e. those related to the product or process, which should be new or improved and available to the potential user (Oslo Manual..., 2018).

Competitiveness has long been the subject of many theoretical studies and research. However, many of its aspects remain undiscovered and interesting from a cognitive point of view (Szwacka-Mokrzycka, 2017). One of such areas is the research problem included in this study. It concerns the relationship between having a long-term action plan related to innovations and the type and degree of competitiveness factors employed by innovative enterprises. The research included in the study is a response to the existing research gap indicated by Walczak (2010), who states that an interesting issue could be the identification of particular factors that are of key importance and which have the greatest impact on competitiveness in a particular group of enterprises (e.g. in a given industry or sector). It should be noted that this article in its entirety is to a certain extent filling the research gap indicated by the mentioned author.

Competitiveness issues are particularly interesting especially when considering current market realities. According to Baumol (2002), the distinctive feature of a competitive market economy is a unique tendency to stimulate economic growth through innovation (in market capitalism regarded as "machine of innovation"). Market realities such as continuing globalization and integration of markets, constantly changing the market environment, as well as intense technological development, make competitiveness one of determinants and a perspective of assessing the functioning of a company on the market. In addition, it is perceived as an essential condition for development. Competing and competition are key characteristics of the market economy. Competition is a fairly clear concepts, defined, for instance, as the phenomenon of aiming at achieving similar goals by rival participants, the situation wherein actions to achieve goals undertaken by one firm are hampered by actions to achieve the same goals by others (Kraszewska \& Pujer, 2017; Lachiewicz \& Matejun, 2009; Stankiewicz, 2002, 2005). Competitiveness, on the other hand, can be interpreted at various aggregate levels ranging from micro, through meso- and macro- to mega-economic (Dróżdż, 2014). According to Pawlak and Poczta (2011), many economic theories refer to competing, including the theory of economic growth, management location theory, and the theory of international migration of production factors.

The presented diversification on many levels means that there is no proper and universal definition of competitiveness. In many interpretations, however, it is repetitively defined as the ability of the subject (country, region or industry) to compete and be competitive (Stankiewicz, 2005, Industrial Structure Statistics, 1994, 1996; Kraszewska \& Pujer, 2017; Zorska, 1998). In the context of the study, the definition at the company level is especially interesting. Beyer (2012) interprets competitiveness as the ability to stay on the market and the ability to develop the firm, but also to oppose other co-existing entities on that market. From the market perspective, competitiveness can be defined as the ability to provide customers with the right products (services) of adequate quality, at the right time and place, so that customer needs are met faster and more effectively compared to other companies.

\section{Competitiveness of enterprises}

\subsection{System approach to the competitiveness of enterprises}

In view of the considerations in the study, the interpretation of competitiveness proposed by Stankiewicz (2005) was applied, in which he views it as a system co-created by four elements (Table 1). The cited author states this system is composed of potential, advantage, tools and a competitive position proposed by Abbas (2000). The author regards competitiveness as the ability of firms to innovate and be flexible, which is manifested in gaining a competitive advantage. This definition shows the synergy of these two concepts.

Table 1. Characteristic of competitive system components (source: own study based on Stankiewicz, 2005)

\begin{tabular}{|l|l|}
\hline Competitive system elements & \multicolumn{1}{|c|}{ Characteristic } \\
\hline Competitive potential & $\begin{array}{l}\text { - Material and immaterial resources; } \\
\text { - Key capabilities and competencies - enable the firm to obtain sustainable and diffi- } \\
\text { cult to eliminate the advantage over competitors. }\end{array}$ \\
\hline Competitive advantage & $\begin{array}{l}\text { - The result of effective and diverse components of the competitive potential; } \\
\text { - Components of the potential allow the firm to generate an attractive market offer, } \\
\text { but also effective directing tools. }\end{array}$ \\
\hline Competitive tools & $\begin{array}{l}\text { - Instruments and methods of building customer capital and creating goodwill that is } \\
\text { consciously used for a specific purpose. }\end{array}$ \\
\hline Competitive position & - Firm's result of competing in a given sector in relation to competitors. \\
\hline
\end{tabular}


Walczak (2010) also emphasizes the significant role of innovativeness in the context of competitiveness. Wherein modern enterprises must look for new management solutions, resorting especially to fresh and innovative undertakings, which concurrently differentiate the firm from the rivals and are hard to imitate. A certain compilation of quoted definitions and considerations on competitiveness and innovativeness is their combination with elements of management. Compilation can be regarded as the firm's expansion strategy, the key element of which is striving for obtaining a longterm competitive advantage (an element of competitiveness), and one of its kinds is the innovation strategy (an element of innovativeness and management).

The growth strategy is a component of the enterprise management system that can be implemented, for example, by the method of innovation, technology, processes or knowledge management. The continuous improvement of this system and the use of these methods, according to Stabryla and Małkusa (2012), allows the firm to gain a satisfactory level of competitiveness, necessary to obtain a strong competitive position on the market. Its sustainability and improvement require the firm to implement a strategic plan based on innovative and effective activities, considering the inner potential of the organization and its surrounding. The strategy is fundamental for decisions regarding innovations and changes (Sundbo, 2001), and has a significant impact on the scope and speed of innovations being launched (Stieglitz \& Heine, 2007).

An integral element linking the management system with innovativeness is an innovation strategy. It can be one of the strategic prerequisites for the firm's growth. An innovation strategy in the following research is defined as a long-term action plan related to innovativeness or innovation management. According to the relevant literature, an innovation strategy is a fundamental premise in a firm's growth, which is based on the innovative process (Bessant $\&$ Tidd, 2007; Kąpa-Kejna, 2009). In the economic discourse, it is therefore noticeable that there is a close relationship between innovativeness and having an action plan (strategy) related to innovations. Pondering other considerations regarding the innovation strategy, it is indicated that it should be tailored in terms of many attributes, including such as competitive position, resources, life cycle or the company development aspirations. With respect to the issue of an innovation strategy in terms of the first of these, it should be stated that there is a link between a long-term plan of innovative activities and a competitiveness component, which is the competitive position. The latter is, among others, a competing factor used by the firm. It can, therefore, be assumed that competition tools depend on the fact of having an action plan related to innovation management.

Summarizing considerations hitherto, it is crucial to point to the significance of the strategic approach to implementing innovations which is emphasized by the previously cited Bessant and Tidd (2007) and is directly dependent on aware building and developing of innovative capabilities in an organization. The considerations presented so far have become the basis for constructing the assumptions of two research hypotheses, which are presented in the methodological part of the study.

\subsection{Competitiveness factors of enterprises}

Competitiveness factors allow the company to stand out from the competitors on the market and thus gain customers. According to Bednarz (2013), the objective of competitiveness tools is to help obtain a transaction beneficial to both parties (entrepreneur and buyer). As a result of cooperation at a satisfactory level, it is possible to build trust with the other party and to maintain customer loyalty in the long-term. According to Haffer (2002) and Charucka (2014), the determinants of competitiveness are defined based on its sources and only when they are used at the right time success can be obtained.

The number and type of competitiveness factors may be different depending on many criteria, for instance, sector specifics, product type, competitors' activity or stage of market development. There are many determinants in the subject literature, and none of them is entirely suitable for use. The most general and synthetic approach to this issue seems to be the one proposed by Adamkiewicz-Drwiłło (2002). According to her, competitiveness factors can be divided based on two criteria. The first is the type of decisions taken, which distinguishes internal and external factors. This method of differentiation allows gaining a market position, in which the firm can withstand the impact of negative forces or influence them - figure 1 (Porter, 2001).

Internal determinants are elements of the firm's autonomous operating zone and include decisions regarding, among others, reducing own costs, shaping the production volume, increasing quality and offering new products or services, and increasing productivity (Sieradzka, Luft, \& Walasik, 2015). The ability to control and steer these conditions gives great opportunities for effective influence on the level of competitiveness of an enterprise, which can be determined based on the operation of two subsystems of factors. First, it is the efficiency of production and economic activity, and secondly the competitive ability of manufactured products. The literature indicates the connection between these subsystems and the correlation between competitiveness and the creation of conditions for increasing sales figures. As a result, production performance indicators and the economic activity improve, which in turn results in enhanced price competitiveness of the firm. Both competitiveness subsystems contain internal factors that are interrelated and conditioned (Assylbekova, 2016). 


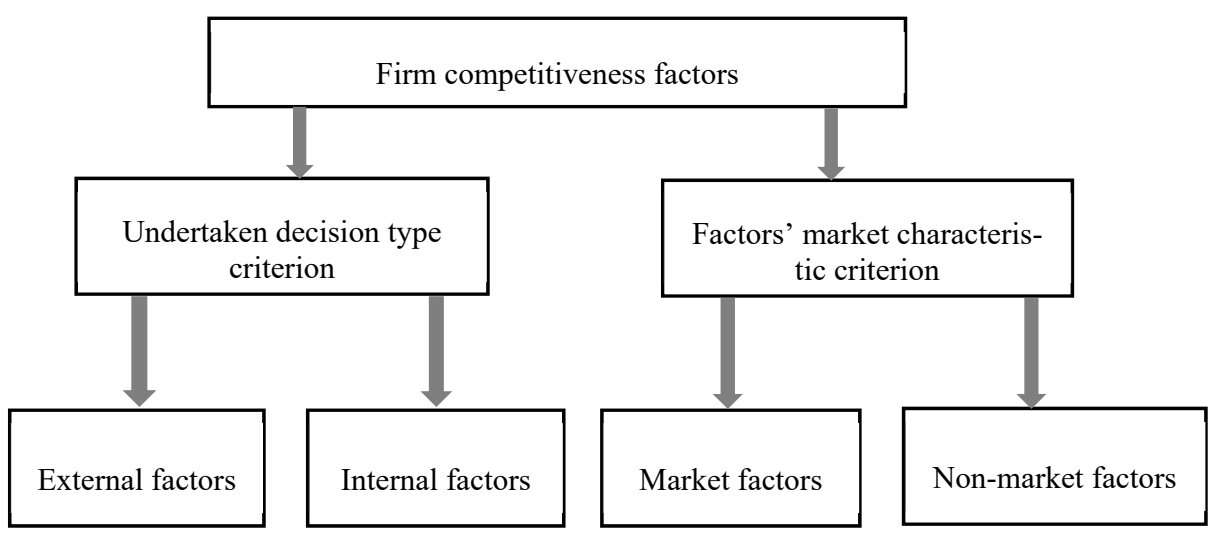

Figure 1. Classification of a firm's competitive factors (source: own study based on Adamkiewicz-Drwiłło (2002)

The characteristics of external factors are concentrated around the microenvironment (close environment) and macroenvironment relevant to the economy of a given country. In view of the second of these, it is worth to mention that there are factors in the following areas: political, legal, economic, socio-cultural, technological, demographic and natural. The factors derived from microenvironment have a much greater impact on the functioning of the company. It is important in the context of making economic decisions in economic units as well as from the point of view of the company's operations. A characteristic feature of microenvironment factors is the fact that an enterprise may have an impact on them depending on the strength associated with the competitive position achieved - the higher the position, the stronger the impact (Assylbekova, 2016; Kozioł, 2008).

A narrower classification of competitiveness factors is the one that differentiates them in line with the market criterion into the market and non-market ones. The former includes, for example, the quality, price or terms of sales of the good. All the above mentioned, except for the prices, are directly proportional to competitiveness level. The principal determinant among non-market factors is technical progress, which should be understood as a manifestation of innovativeness and which affects the quantity and quality of goods and services (Sieradzka, Luft, \& Walasik, 2015). As Skawińska states (2002), technical progress evokes positive changes in the technical structure of the enterprise, resulting from the increase in the technical level, which is referred to as the utility character of the economic effect. The saving character of the mentioned effect arises as a result of the transformation taking place in the technical structure of the company, which causes changes in the value of technical and operational indicators or economic indicators of the production activity.

From the perspective of this study, the attention will be focused on internal factors and those from the microenvironment, considering their market character as well as non-market character. In the face of the already signalled diversity of the classification of competing factors of enterprises, for the sake of this study, they were presented in a synthetic way in Table 2 .

Table 2. Firm's competitiveness factors (source: own study based on Skawińska (2002); Chrobocińska and Juchniewicz (2010);

Stankiewicz (2005); Haffer (2002); Kotler (1999); Walczak (2010); Filipowska (2013); Adamkiewicz-Drwiłło (2002); Bednarz (2013))

\begin{tabular}{|l|l|}
\hline \multicolumn{1}{|c|}{ Competitiveness factors } & \multicolumn{1}{|c|}{ Author } \\
\hline Product, price, place, promotion & Kotler \\
\hline Product, price, distribution promotion, people, process, material proof and pleasure & Bednarz \\
\hline Quality, price, communication method, promotion, brand of products & $\begin{array}{l}\text { Chrobocińska, Juch- } \\
\text { niewicz }\end{array}$ \\
\hline Quality, price, communication and information, service and services & Stankiewicz \\
\hline $\begin{array}{l}\text { Quality, price, brand of the product, company image, scope of after-sales services, payment } \\
\text { terms, reputation of the company }\end{array}$ & Skawińska \\
\hline $\begin{array}{l}\text { Quality of management and time management, product, distribution, marketing, technologies, } \\
\text { place on the market (company trademark, credibility patents), company's uniqueness }\end{array}$ & Haffer \\
\hline $\begin{array}{l}\text { Quality, price, sales conditions, technical progress } \\
\text { Quality, innovativeness of offered products, strategic knowledge resources, organizational } \\
\text { structure, organizational culture, key competencies, brand, reputation, marketing activity, } \\
\text { ability to manage company resources }\end{array}$ & Adamkiewicz-Drwiłło \\
\hline $\begin{array}{l}\text { Product quality, product price, innovation and technological advancement of a given eco- } \\
\text { nomic entity, network of contacts and partners, own investments and the possibility of obtain- } \\
\text { ing capital, availability and method of financing the business, business environment. }\end{array}$ & Filipowska \\
\hline
\end{tabular}


Due to the diversity in the approach to competition factors employed by business entities, a compilation of approaches is frequently used. For example, Kotler (1999) indicates that the most popular concept of competitiveness factors is that resulting from the so-called marketing-mix, which in its basic form considers four components: product, price, distribution, promotion. These are extended by Bednarz (2013) for people, process, material proof and pleasure. Haffer (2002) recognizes that the tools are derived from the sources of competitiveness, which include: production, distribution, marketing, technology, market position (company trademark, credibility, patents), company uniqueness, quality of management and time management. The relation between the sources of competitiveness and the tools employed was also noticed by Chrobocińska and Juchniewicz (2010), just like Filipowska (2013). In their opinion, the instruments of competition include quality, price, communication method, promotion or a product brand. Stankiewicz (2005) presented a very similar classification of competitiveness instruments, in line with which they are divided into four groups related to:

- Service and support - scope, quality of sales services and after-sale services, availability of spare parts, convenience of time and place of products purchase, ease of market access, etc.

-Quality - novelty, diversification, brand, differentiation, assortment range, new and improved products launch, eco-friendliness, etc.

- Price - payment terms, new products' prices, price range, promotional prices, installments, etc.

- Communication and information (in the field of marketing) - personal sales, promotion, advertising, loyalty programs, etc.

Considering the discussed competitiveness factors, the crucial issue is their synergistic use. Factors of competitiveness should be viewed in a comprehensive approach, recognizing their interrelationships and interdependencies. In order to build a strong competitive position on the market, it is crucial to consider the factors' interactive nature, i.e. the synergy of them playing together. According to literature, they should not be perceived as single isolated variables, but as a set of mutually dependent elements that occur in the same time horizon and interpenetrate. The described approach indicates the effect of their synergistic impact on the competitiveness of the company, which is confirmed in the practice of management (Bednarz, 2014; Walczak, 2009).

For the purposes of the empirical part of this article, the compilation of approaches to competitiveness factors was presented in Table 2 and the hitherto deliberation. Based on the analysis of the literature on the subject, own division of competitiveness factors applicable to the study of the phenomenon in innovative enterprises was constructed. This classification was composed of five groups of tools, which included:

-Quality;

- Price;

- Marketing-related activity elements (e.g. communication styles, image and company's reputation or promotion);

- Logistics activity (including distribution);

- Innovativeness (understood as technology) which in practice occurs in all the above factors.

\section{Research methods}

In reference to the literature on the subject and the complex issues of competitiveness and innovativeness, the study formulated the research objective as the identification and assessment of competitiveness factors in innovative enterprises that had an innovation management plan for the following years and those that did not have it in their future growth strategy.

In view of the presented research objective, the following research hypotheses were formulated:

1. There is a statistically significant difference in the assessment of competitiveness factors by respondents representing enterprises with an innovation action plan and that who do not have such a plan.

2. There is a statistically significant relationship between having a long-term action plan related to innovation and (competitiveness factor) competing with innovativeness.

In view of the formulated goal and research hypotheses, innovative enterprises of various size from the area of the Warmia-Mazury Voivodeship and neighboring regions were accepted as the subject of the research. According to the Oslo Manual... (2018), innovation firm is a unit, which launched one or more innovations into the market during the period considered. The research encompassed 101 such as business entities. The definition of an innovative company should be supplemented with the information that the suggested timeframe for observation is a three-year period. The research group was divided into two groups, the first being companies that had a long-term action plan in the field of innovation management, the other one, did not have such a strategy. The companies for research were selected nonrandomly. The research object was the factors determining competitiveness in innovative enterprises, which were selected for research as described in the previous chapter. The time of realization of the described research is 2017-2018, while the data obtained as a result of these studies concerned the years 2015-2017. The length of the analyzed period was in accordance with Oslo Manual... (2005, 2018), which is the main resource for issues related to innovation and 
innovativeness. According to it, the proper period for examining the innovative activity of market entities and analyzing all aspects related to this activity is a three-year period.

Several research methods were used for the research. The first one was the analysis of domestic and foreign literature sources in the field of discussed issues, which lead to the identification of the competing factors, and to the specification of the aspects related to the innovativeness of enterprises, including defining the concept of an innovative company. It should be noted that the Oslo Manual was the methodological basis for the development of the part of the article related to innovation. In 2018, the OECD countries developed its latest version. However, due to the mentioned period of research, the application of the guidelines contained therein was not fully possible. For this reason, the third edition of the source document (Oslo Manual..., 2005) was also taken as the basis for the methodological assumptions.

In order to develop the empirical part of the article, the survey method was used, which involved obtaining the desired information from respondents using observation techniques in both direct (personal, telephone) and indirect (correspondence) form (Szreder, 2004). Using this method, a measurement research tool was used in the form of an original questionnaire. Respondents assessed the factors with which their entities competed on the market. For the analysis of qualitative data from surveys, the Likert scale from 1 to 5 was applied, where 1 meant a very low degree of competition for a given factor on the market, and a score of 5 indicated a very large use of the competitive component. In addition, a value of 0 was introduced, which indicated the lack of competition with a specific component. Next, a statistical method was applied to analyze the results of the study with the use of Statistica 13.1 software, whereby elements both descriptive statistics and statistical analyses were applied in order to verify both research hypotheses. With respect to the first hypothesis, which concerns the occurrence of significant differences in the assessment (competitiveness factors) between the two studied groups, the arithmetic mean was used. In order to determine the statistical significance of these differences, non-parametric Mann-Whitney $U$ test for two independent samples with a population greater than 20 each was applied. The test was calculated using the following formula (Stanisz, 2006):

$$
Z=\frac{\frac{R_{1}-R_{2}-\left(n_{1}-n_{2}\right)(n+1)}{2}}{\frac{\sqrt{n_{1} n_{2}(n+1)}}{3}},
$$

where $Z$ - the Mann-Whitney U test result; $R_{1}, R_{2}$ - the sum of ranks appointed to the values of the first/second sample; $n$ - total number of observations; $n_{1}, n_{2}$ - the number of observations in the first / second sample.

The above-presented test was applied to the following statistical zero hypothesis $\left(\mathrm{H}_{0}\right)$ : There is no statistically significant difference in the assessment of competitiveness factors between the two compared study groups. Therefore, the alternative hypothesis $\left(\mathrm{H}_{1}\right)$ asserted that: Between the two compared research groups there is a statistically significant difference in the assessment of the competitiveness factor, which was innovativeness.

The verification of the second of the research hypotheses used was analyzed with the $2 \times 2$ contingency table, and three statistical parameters were used to confirm the results contained therein. The first of these was the $\chi^{2}$ independence test (chi-square), which served to confirm or deny the assumptions resulting from the contingency table. The following formula was applied (Stanisz, 2006):

$$
\chi^{2}=\sum \frac{(O-E)^{2}}{E}=\sum_{i=1}^{k} \sum_{j=1}^{p} \frac{\left(n_{i j}-E_{i j}\right)^{2}}{E_{i j}}
$$

where: $E$ - expected cell frequency; $O$ - observed cell frequency.

In order to refine the results of research, as well as indicate the strength of correlation between the studied phenomena, two statistical coefficients were used to verify the second hypothesis. The first of these was Pearson's (P) contingency coefficient, which is a measure of the relationship between variables and is expressed by the following formula (Stanisz, 2006):

$$
C=\sqrt{\frac{\chi^{2}}{\left(N+\chi^{2}\right)}}
$$

where: $\mathrm{C}$ - two variables Pearson's C contingency coefficient; $\chi^{2}-$ two variables chi-square test result; $\mathrm{N}-$ number of observations

Due to the disadvantage of the contingency coefficient wherein the maximum value is dependent on the table size (this coefficient reaches the value 1 only for an infinite number of categories), the last of the measures used was the $\mathrm{V}$ Cramér's coefficient (V) in the following formula (Stanisz, 2006): 


$$
V=\sqrt{\frac{\chi^{2}}{\operatorname{Nmin}(k-1, p-1)}},
$$

where: $\chi^{2}$ - chi-square test result for a pair of variables; $N$ - total number of observations; $k$ - the number of columns; $p$ - the number of rows; $\min (p-1, k-1)$ - the lower value from $(p-1)$ or $(k-1)$.

The strength of the correlation (dependency) in the coefficients was evaluated by means of the classification proposed by Guilford, i.e. the value 0 meaning lack of correlation, while values from the interval:

$-(0.0 ; 0.1>$ slight correlation;

$-(0.1 ; 0.3>$ weak correlation;

$-(0.3 ; 0.5>$ average correlation;

$-(0.5 ; 0.7>$ high correlation;

$-(0.7 ; 0.9>$ very high correlation;

$-(0.9 ; 1>$ almost full correlation;

- while 1 means full correlation.

With reference to each of the presented statistical coefficients depicting relations between variables, the following (statistical) null hypothesis $\left(\mathrm{H}_{0}\right)$ was set: The examined features are independent. Subsequently, the alternative hypothesis $\left(\mathrm{H}_{1}\right)$ assumed that: The studied features are interdependent. The confidence level $p=0,05$ was used to check the accuracy of statistical hypotheses both in terms of coefficients and Mann-Whitney U test. During their verification, any result lower than this level resulted in the rejection of the null hypothesis and in favor of the alternative. The result greater than 0,05 would lead to the acceptance of the null hypothesis.

\section{Research results}

\subsection{Description of the research sample}

In the scope of wide research on the level of innovative activity of enterprises, 101 innovative business entities representing Warmia-Mazury Voivodeship and adjacent regions were examined. Due to incomplete data from 3 companies, the analyses included 98 companies. As mentioned in the methodological part of the study, business entities were grouped based on having or not a long-term action plan related to innovation management, which led to distinguishing two groups of innovative enterprises (two research groups). The first one was characterized by having a long-term plan of action related to management and innovative activity for the future $-61.22 \%$ of all surveyed units (Figure 2). The remaining part (38.78\%) are innovative companies that did not have such a plan.

Having a long-term action plan related to innovations is a very important aspect of business management in the context of its level of innovativeness. Often regarding the case of innovative activity, an unfavorable tendency to the one-time introduction of innovations can be noticed, which is usually an occasional response to competitors on the market. On the one hand, this is a positive phenomenon, because, as Lescovar-Spacapan and Bastic (2007) claim, companies that react quickly to change can more effectively identify new opportunities and ideas needed for their functioning. On the other hand, for this to happen, the above-mentioned immediate market reaction requires adaptation of the market strategy.

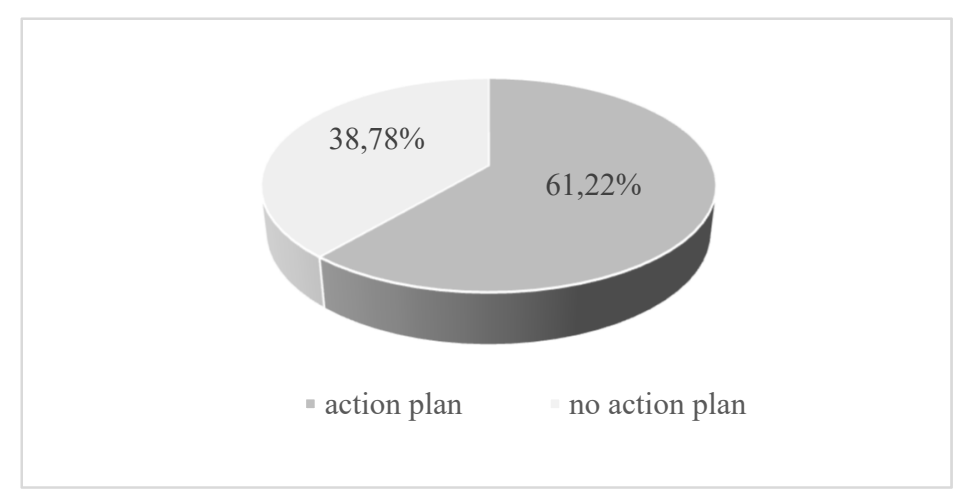

Figure 2. Having a long-term plan of action by the surveyed enterprises (source: own study based on own research)

According to many scholars, innovation activity is a key condition to become competitive, whereas the increase in their innovation should not be the result of occasional actions, but rather the result of a purposeful innovation strategy (Kickul \& Walters, 2002; Poznańska, 2001; Stieglitz \& Heine, 2007). For this reason, in order to obtain and especially maintain a competitive advantage on the market, it is necessary to design, prototype and introduce novelty (innovation) 
constantly as part of business management and innovation activity. Only such activities can ensure economic entities gain and maintain a competitive position on the market. Abandonment of innovative activity will not only hinder given enterprise's growth but also make it regressive and behind its competitors. A highly desirable component of innovation strategy is a long-term action plan related to innovations, which supports the innovation activity and innovativeness of the company. This kind of strategic agenda was in possession of $61.22 \%$ of the surveyed enterprises. Other entities $(38.78 \%)$, which did not have such an innovation management plan, were potentially more exposed to stagnation or even a loss of competitive position relative to market rivals.

Based on the collected data, it was also noticed that there were 91 service and 10 production enterprises in the research group. The largest number of entities participating in the research were large companies - employing 250 or more employees $-32.67 \%$ (Figure 3). Nearly a quarter of the surveyed entities were micro firms, employing up to 9 employees.

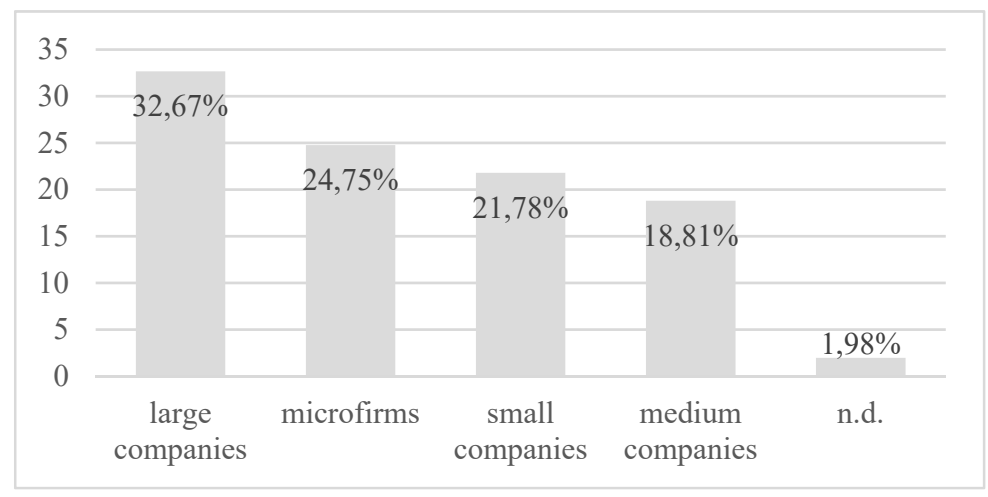

Figure 3. Size of enterprises participating in research (source: own study based on own research)

Based on the presented data, it can be observed that the size structure of the surveyed units was not very diverse. Companies in the so-called sector of small and medium-sized enterprises (SMEs) were most of the surveyed business entities (together with microenterprises they constituted $65.34 \%$ of all surveyed enterprises). Only $1.98 \%$ of respondents did not declare the size of their enterprise. Therefore, these units were not included in further analyses.

\subsection{Assessment of competitiveness factors}

With respect to the objective of the study, it was necessary to calculate the arithmetic averages of the assessments attributed by the respondents to a particular competitiveness factor. Average scores of the surveyed entities without separation into two groups ranged between 4.33 points (quality) and 2.95 points (innovation) on a 0 to 5 point scale. As mentioned in the methods part, all analyses were conducted with a distinction between two groups of innovative enterprises based on them having or not a long-term action plan related to innovations. According to these assumptions, based on the arithmetic mean it was concluded that the key factor of competitiveness in the research was quality. This situation occurred in both groups - companies with an action plan assigned 4.62 points to it, while the second group surveyed: assigned 4.05 points (Table 3 ).

Table 3. Average assessment of competitive factors of innovative enterprises (breakdown based on having or not having a long-term action plan) - data in points (source: own study based on own research)

\begin{tabular}{|c|l|c|c|c|c|c|}
\hline No. & \multicolumn{1}{|c|}{ Particulars } & Quality & Price & $\begin{array}{c}\text { Marketing } \\
\text { activities }\end{array}$ & $\begin{array}{c}\text { Logistics } \\
\text { activities }\end{array}$ & Innovativeness \\
\hline 1 & Action plan & 4.62 & 3.53 & 3.75 & 3.37 & 3.40 \\
\hline 2 & No action plan & 4.05 & 3.32 & 2.63 & 2.63 & 2.50 \\
\hline 3 & Average score for both groups & 4.33 & 3.42 & 3.19 & 3.00 & 2.95 \\
\hline 4 & Point 1 and 2 difference & 0.56 & 0.22 & 1.12 & 0.74 & 0.90 \\
\hline
\end{tabular}

Verifying the average scores, calculated from both studied groups, one can notice an interesting phenomenon. Among the factors employed to compete on the market, innovation was in the last place with a score of 2.95 points (similarly in companies without an action plan -2.50 points).

It is worth to indicate that the conducted own research in the area of the average assessment of competitiveness factors (without the distinction between the surveyed groups) was similar to those implemented in 2014 by Bednarz (2014) regarding the competitiveness of Polish food industry enterprises. Analyzing the results of the research conducted by the above author, it should be noted that among the tools of competition, the quality of products (indicated by $64 \%$ of the surveyed enterprises) was ranked first, as in own research. A further hierarchy of competitiveness factors 
was also coherent with their research. The price level was considered the second most important instrument of competition, which was indicated by $32 \%$ of the surveyed units. The third-place includes factors related to marketing activities (among them the method of communication via the Internet $-29 \%$ etc.). Because of the lack of instruments related to logistics activities, the fourth place in the above-cited author's research was occupied by launching new products as well as upgraded existing products (an aspect related to innovativeness). Similarly, this factor also took the last place in our research. It should also be added that the hierarchy of competitiveness factors presented in the compared studies was identical to the results obtained by the group that did not have an action plan in our research.

The low result of innovativeness as a factor of competitiveness in the case of own research and the compared research can be explained by a close link between innovativeness and quality. At the microeconomic level, innovativeness often generates and affects the higher technological quality or the quality of marketing and management elements. This can be confirmed by theoretical considerations such as Świtalski (2005). The author cites that introducing innovations in addition to the fact that it may lead to more efficient functioning of enterprises (e.g. reduce its costs), it also allows to increase the utility of achieved results, which is manifested, for example, in higher usability or technical quality of products (services) in a situation of production costs reduction in conditions of non-deterioration of technical and usable quality or the cost of obtaining the product has not increased. For this reason, the high average rating obtained by quality was in a sense the result of various types of activities related to innovation activity (innovativeness). These include, for example: the use of improved (modernized) or completely new production methods and techniques to improve the quality of products, introduction of management methods aimed at improving the quality of working conditions, e.g. through the use of innovative flexible forms of employment, working time, remuneration and also lean management or other methods of business management (Organiściak-Krzykowska, Walkowiak \& Nyklewicz, 2014). Recognition of quality as the most important factor of competitiveness and innovativeness in the last place can be explained by the described cause and effect relationship. A disadvantaged situation would be the one, where the described relationship did not take place meaning that innovativeness was not perceived as a means of competition (Volberd, 2000), which in the perspective of constant technological development in the $21^{\text {st }}$ century would be a very disadvantaged situation. Since the '70s of the last century onwards, entrepreneurs gradually realized that quality and costs are not a guarantee of long-term success. Compelled to compete on costs, product features and perfection, they focused their efforts on increasing innovativeness.

In the context of the presented data, it should be noted that in the case of each of the listed competitiveness factors, the assessment values assigned by companies with an action plan were higher than those proposed by the second group. The significant difference in this regard occurred in relation to marketing activities - the difference of 1.12 points. On the other hand, the least divergent answers were related to the price factor - a difference of 0.22 points. Consequently, it can be concluded that all tested components of competitiveness without exception were more important for enterprises with planned innovation activities than for those that did not encompass such activities.

The hitherto analyses show that there were differences in the assessment of each of the competitiveness factors, with values ranging from 0.22 to 1.12 points. From the mathematical perspective, such disproportions can be considered minor. However, to gain further insights including the level of the variability of the presented assessments, statistical analysis with the Mann-Whitney $U$ test for two independent groups was performed (Table 4).

Based on a non-parametric test used to determine statistically significant differences, it was observed that the two studied groups differed with statistical significance in the assessment of competitiveness factors such as quality, marketing, logistics activities, and innovativeness. Only in the case of the price, no such variability was noticed. The applied statistical test confirmed the earlier assumptions based on the analysis of average ratings of competitiveness factors.

Table 4. Mann-Whitney U test results (source: own study based on own research using the Statistica 13.1 software)

\begin{tabular}{|l|c|c|c|c|c|}
\hline \multicolumn{1}{|c|}{ Competitive factors } & $\begin{array}{c}\text { Rank sum } \\
\text { (group 1) }\end{array}$ & $\begin{array}{c}\text { Rank sum } \\
\text { (group 2) }\end{array}$ & $\begin{array}{c}\text { Mann-Whitney U } \\
\text { test result }\end{array}$ & $\begin{array}{c}\text { Z-corrected test value } \\
\text { (more than 20 units) }\end{array}$ & $\begin{array}{c}\mathrm{p}-\text { confidence } \\
\text { level }=0,05\end{array}$ \\
\hline Price & 3100.5 & 1750.5 & 1009.5 & 0.991987 & 0.343196 \\
\hline Quality & 3429.5 & 1421.5 & 680.5 & 3.732708 & 0.000818 \\
\hline Marketing activities & 3404.5 & 1446.5 & 705.5 & 3.252420 & 0.001554 \\
\hline Innovativeness & 3561.0 & 1290.0 & 549.0 & 4.429149 & 0.000017 \\
\hline Logistics activities & 3260.5 & 1590.5 & 849.5 & 2.166966 & 0.034475 \\
\hline
\end{tabular}

Summarizing this part of the research results, it should clearly be stated that the study showed statistically significant differences between the studied groups in their use of competitiveness factors. The analysis showed that quality was the most popular factor of competition in both groups. Despite this, a statistically significant difference between 
the groups in the assessment of the quality factor was observed. The same situation was noted in the case of three other components (marketing, logistics and innovativeness), as indicated by the Mann-Whitney U test.

According to the literature on the subject presented in the earlier part of the study, innovativeness is very often among competitiveness factors and indicates its significant role and synergy with the company's strategy and competitiveness. Due to this fact, the research attempts to extend the analysis of this issue. In connection with the presentation of the problem in the way described, the second of the research hypotheses included in the study was assumed and verified (there is a statistically significant correlation between having a long-term action plan related to innovation and competing with innovativeness). Analyzing the data in the two-way contingency table regarding the differentiation between innovativeness and having an action plan, it should be noted that the greatest disproportions occurred at the level of 5 points (Table 5). In this case, the results should be interpreted in the following way: among all enterprises that rated the factor of competitiveness as innovativeness, as many as $95 \%$ were represented by a group of companies having an action plan, and 5\% had no such plan. At the same time, it can be stated that among entities with a long-term plan, $31.67 \%$ rated innovation as a very important factor of competitiveness ( 5 points). However, more companies from this group $(33.33 \%)$ considered innovativeness as a factor significantly affecting competitiveness (4 points).

Table 5. Assessment of innovativeness as a factor of competitiveness in two groups studied - contingency table (data in $\%$ ) (source: own study based on own research using the Statistica 13.1 program)

\begin{tabular}{|l|c|c|c|c|c|c|c|}
\hline \multicolumn{1}{|c|}{ Particulars } & \multicolumn{7}{c|}{ Assessment of innovativeness level } \\
\hline Assessment value & 0 & 1 & 2 & 3 & \multicolumn{2}{c|}{4} \\
\hline \multicolumn{7}{|c|}{ Firms not having an action plan } \\
\hline Column \% & 33.33 & 75.00 & 75.00 & 48.15 & 28.57 & 5.00 \\
\hline Row \% & 2.63 & 15.79 & 23.68 & 34.21 & 21.05 & 2.63 \\
\hline \multicolumn{7}{|c|}{ Firms having an action plan } \\
\hline Column \% & 66.67 & 25.00 & 25.00 & 51.85 & 71.43 & 95.00 \\
\hline Row \% & 3.33 & 3.33 & 5.00 & 23.33 & 33.33 & 31.67 \\
\hline
\end{tabular}

The data presented in Table 5 show that the average score - 3 points - was most commonly (34.21\%) attributed by a group of companies without a plan to innovativeness. Furthermore, the two groups were also observed to be least different between each other. Of all the companies that rated innovation at 3 points, $48.15 \%$ did not have an innovation activity plan, and $51.85 \%$ had such an agenda. Based on the data included in the contingency table, an interesting distribution of assessments attributed to innovativeness can be noticed. Along with the increase in the value of the assessed factor of competitiveness, the share of companies without an action plan decreased $(75.00 \% ; 75.00 \% ; 48.15 \%$; $28.57 \% ; 5.00 \%)$, while the percentage of enterprises having it increased $(25.00 \% ; 25.00 \% ; 51.85 \% ; 71.43 \% ; 95.00 \%)$.

Based on the data included in the contingency table, the analyses conducted so far reveal symptoms and allows inferences about the correlation between innovativeness and the fact that the company has a long-term action plan in the field of innovation. In order to identify the correlation between the said variables, three statistical analyses were performed (Table 6).

Table 6. Statistical analyses results (source: own study based on own research using the Statistica 13.1 software)

\begin{tabular}{|l|c|c|c|}
\hline & Chi-square test $\left(\chi^{2}\right)$ & $\mathrm{df}$ & $\begin{array}{c}\mathrm{p}-\text { confidence level } \\
=0.05\end{array}$ \\
\hline Pearson Chi-square $\left(\chi^{2}\right)$ & 22.93003 & $\mathrm{df}=5$ & $\mathrm{p}=0.00035$ \\
\hline Contingency coefficient $(\mathrm{C})$ & 0.4354469 & & \\
\hline Cramér's V coefficient $(\mathrm{V})$ & 0.4837146 & & \\
\hline
\end{tabular}

The result of the $\chi^{2}$ test $\left(\chi^{2}=22.93003\right.$ at confidence level $\left.\mathrm{p}=0.00035\right)$ confirmed the previous assumptions resulting from the analysis of the data in the contingency table. The correlation between competing with innovativeness and having an action plan related to innovations by an innovative company has been confirmed by the analysis of coefficients. The strength of this relationship was determined as average by two coefficients: contingency $(\mathrm{C}=0.4354469)$ and Cramér's $\mathrm{V}=0.4837146$.

Summarizing the statistical analysis related to the verification of the second research hypothesis, it should be noted that the contingency table provided for the initial identification of the relationship between competing with innovativeness and holding an innovative action plan related to innovation. This correlation was additionally confirmed by performing analyses based on coefficients determining dependence strength. At the same time, it was possible to 
determine the strength of dependence to be at the average level. According to the classification presented in the methods part of the study, this correlation is characterized by the level of dependence within the limits of $(0.3 ; 0.5>$.

With respect to the previous considerations in the empirical part of the study, it should be stated that in the scope of methodological assumptions, both research hypotheses were verified; thus, the set research objective was realized. Consequently, the research gap formulated in the form of a research problem mentioned in the study was filled to some extent. Regarding the research problem and considering the analysis of the research material, it should be stated that the type and degree of competitiveness factors used by innovative companies depend on having a plan related to innovation activities. In both studied groups (those with and without a plan) there were statistically significant differences in the assessment of competitive components. The exception was the price for which this relationship was not noticed. At the same time, all determinants of competitiveness were assessed higher by firms with a long-term plan of action than by the firms representing the second group. Both studied groups recognized quality as the most important element of competitiveness. In addition, innovativeness was recognized as a factor with an average strength correlation between its assessment and the fact of having a long-term action plan related to innovation. However, these results were not statistically significant and thus did not allow for a straightforward confirmation or negation of the research hypothesis set in the study.

\section{Conclusions}

In the described studies about the evaluation of competitive factors, there were 98 innovative enterprises which were divided into two groups. The first group consisted of the companies, which had the long-term plan of action connected with innovations among which there were most of the business entities. Units which were among the second group did not have such plan for the future. Such proportion proves the positive thing about the surveyed group. The mentioned plan as a strategy element allows the enterprise to conduct conscious and well-thought actions among the management of the innovations. It also gives some solutions in the range of activity connected with innovations which enable to hold the competitive position on the market and some of the advantages among the competitors. The group of enterprises which declared lack of action plan connected with innovations was carrying on, managing the innovation occasionally, adapting to the present market situation. In the survey, the enterprises had various innovative enterprises in a range of size. The largest percentage were large enterprises, which are the ones that are hiring more than 250 people. When classifying the micro, small and medium enterprises to the sector of SME, it was noted that they were dominating over large enterprises.

With the use of described research methods, the aim of the purpose was realized, which was the identification and evaluation of competitiveness factors in innovative enterprises, which had the plan of actions in terms of managing the innovations and the ones which did not have the plan in the future strategy of development. During the research, it was noted that despite having a plan of innovations, the most important factor of competitiveness was quality. The way of achieving the satisfying quality in the company are mainly the innovative actions (innovativeness), as an example in the range of creating the products, providing services, managing the enterprise. Therefore, it should be stated that innovative actions may manifest themselves and contribute substantially to quality. High evaluations for the quality result also from the influence of innovative activity on it. At the same time, innovativeness was classified at the last place among the competitive factors. In the perspective of common internationalization and globalization of markets, innovativeness of enterprises should be supplementary to quality and effectiveness. These last ones in a long-time perspective do not ensure the success of a company. It has been seen the phenomenon of the enterprises about their efforts in innovativeness and treating it as the meaningful factor of competing.

In realized research, it was seen that in case of every of evaluated components of innovativeness, the higher grades were assigned by the group of companies that had a plan of actions. The biggest difference in evaluated components of competing was in case of marketing actions. From a cognitive point of view, the interesting was the last place of innovativeness among analysed factors. The cause of such a phenomenon was earlier justified. Usage of a statistical Mann-Whitney $U$ test in relation to the results of research allowed the positive verification of the first research hypothesis about the occurrence of statistically important differences in evaluated factors of competitiveness. Only in relation to the price such dependence was not noted. The extra value of described research is the possibility of their comparison in the relation of used competitive factors with the previous ones, conducted on enterprises of the food industry. Basing on the comparison two analogies were noted. The first one was about the hierarchy of competitiveness factors (made in accordance with the average evaluation for the whole group of 98 enterprises). Second analogy was directly related to the group of innovative enterprises without the long-term plan of action. As a result of comparison with research made by Bednarz, it was noted that this group of subjects was characterized by the same hierarchy of examined instruments as in the case of food industry enterprises.

As to verifying the second hypothesis, the contingency table was used as well with contingency coefficients and Cramér's V. Based on conducted analyses, the correlation of average strength was identified. However, as it turned out the results were not statistically significant. Therefore, it was not possible to accept or reject with clearly the second of the hypothesis. 
The research results presented in the study are of an implication of nature. Based on them it was proved that when having by the innovative enterprises the long-term plan of actions connected with innovations, it will provide the use of competitive factors on a higher level. As a consequence, it affects the gaining of competitive advantage directly, maintaining it and growth of position and shares in the market by such entities. Because not all results were statistically important, in the future, it is worth to identify the correlation between having the plan of actions of innovations and competing with innovativeness.

\section{References}

Abbas, A. J. (2000). Rethinking competitiveness. Advances in Competitiveness Research, 8(1), 1-3.

Adamkiewicz-Drwiłło, H. G. (2002). Uwarunkowania konkurencyjności przedsiębiorstwa. Warszawa: Wydawnictwo Naukowe PWN.

Assylbekova, N. (2016). Przegląd czynników wpływających na konkurencyjność przedsiębiorstw. In P. Urbanek \& E. Walińska (Eds.), Ekonomia i zarzadzanie w teorii i praktyce. Ekonomia i nauki o zarzadzaniu w warunkach integracji gospodarczej (pp. 153-167). Wydawnictwo Uniwersytetu Łódzkiego, Łódź. https://doi.org/10.18778/8088-203-4.09

Baumol, W. (2002). The free market innovation machine. analysing the growth miracle of capitalism. New York University, New York. https://doi.org/10.1515/9781400851638

Bednarz, J. (2013). Konkurencyjność polskich przedsiębiorstw na rynkach europejskich na przykładzie wybranych branż. Gdańsk: Wydawnictwo Uniwersytetu Gdańskiego.

Bednarz, J. (2014). Konkurencyjność polskich przedsiębiorstw przemysłu spożywczego na wybranych rynkach zagranicznych (na podstawie badania ankietowego). In I. Szczepaniak (Ed.), Monitoring i ocena konkurencyjności polskich producentów żywności. Synteza (pp. 130-154). Warszawa: Instytut Ekonomiki Rolnictwa i Gospodarki żywnościowej - Państwowy Instytut Badawczy.

Beyer, K. (2012). Kapitał intelektualny jako podstawa przewagi konkurencyjnej przedsiębiorstw. Zeszyty Naukowe Uniwersytetu Szczecińskiego. Studia i Prace Wydziału Nauk Ekonomicznych i Zarzadzania, 25, 241-254.

Bessant, J., \& Tidd, J. (2007). Innovation and entrepreneurships. Chichester, England: John Wiley \& Sons Ltd.

Charucka, O. (2014). Kluczowe czynniki konkurencyjności MSP i ich wpływ na rozwój gospodarki. Zeszyty Naukowe Uczelni Vistula, 35, 45-67. Warszawa: Wydawnictwo Akademia Finansów i Biznesu.

Chrobocińska, K., \& Juchniewicz, M. (2010). Konkurencyjność sektora MSP na Warmii i Mazurach. Wyd. Fundacja "Wspieranie i Promocji Przedsiębiorczości na Warmii i Mazurach”, Olsztyn.

Dróżdż, J. (2014). Przewagi cenowe polskich producentów artykułów żywnościowych na rynku niemieckim. Roczniki Naukowe Stowarzyszenia Ekonomistów Rolnictwa i Agrobiznesu, 16(3), 80-86.

Filipowska, M. (2013). Konkurencyjność sektora innowacyjnych mikroprzedsiębiorstw $w$ gospodarce opartej na wiedzy na przykładzie Polski w latach 2000-2010 (Doctoral dissertation). Wydział Gospodarki Międzynarodowej. Poznań: Wydawnictwo Uniwersytetu Ekonomicznego w Poznaniu.

Gorynia, M. (2009). Konkurencyjność w ujęciu mikroekonomicznym. In M. Gorynia \& E. Łaźniewska (Eds.), Kompendium wiedzy o konkurencyjności (pp. 67-71). Warszawa: Wydawnictwo Naukowe PWN.

Haffer, M. (2002). Polskie przedsiębiorstwa a wyzwania globalizacji. In M. J. Stankiewicz (Ed.), Determinanty konkurencyjności polskich przedsiębiorstw. Toruń: Wydawnictwo TNOiK.

Hilami, M. F., Ramayah, T., Mustapha, Y., \& Pawanchik, S. (2010). Product and process innovativeness: Evidence from Malaysian SMEs. European Journal of Social Science, 16(4), 556-564.

Industrial Structure Statistics 1994. (1996). Paris: OECD.

Kąpa-Kejna, K. (2009). Innowacje w zarządzaniu przedsiębiorstwem - wykorzystanie metody Kaizen. In A. Pomyklaski (Ed.), Innowacyjność organizacji (pp. 87-96). Łódź: Wydawnictwo Naukowe Wyższej Szkoły Kupieckiej.

Kickul, J., \& Walters, J. (2002) Recognizing New opportunities and innovation. The role of strategic orientation and proactivity in Internet firms. International Journal of Entrepreneurial Behaviour and Research, 8(6), 292-308. https://doi.org/10.1108/13552550210448375

Kotler, Ph. (1999). Marketing. Analiza, planowaniem wdrażanie i kontrola. Warszawa: Wydawnictwo Felberg SJA.

Kozioł, K. (2008). Analiza makrootoczenia. In K. Janasz, W. Janasz, K. Kozio, \& K. Szopik (Eds.), Zarzqdzanie strategiczne. Koncepcje, metody, strategie. Warszawa: Difin.

Kraszewska, M., \& Pujer, K. (2017). Konkurencyjność przedsiębiorstw sposoby budowania przewagi konkurencyjnej. Wydawnictwo Exante, Wrocław.

Lachiewicz, M., \& Matejun, M. (Eds.). (2009). Zarządzanie innowacjami konkurencyjności. Wydawnictwo TNOiK Dom Organizatora. Zeszyty Naukowe Uniwersytetu Szczecińskiego, 25, 241-254. Studia i Prace Wydziału Nauk Ekonomicznych i Zarządzania, Szczecin.

Lescovar-Spacapan, G., \& Bastic, M. (2007). Differences in organizations' innovation capability in transition economy: Internal aspects of the organizations' strategic orientation. Technovation, 27(9), 533-546.

https://doi.org/10.1016/j.technovation.2007.05.012

Organiściak-Krzykowska, A., Walkowiak, R., \& Nykleiwcz, K. (2014). Innowacyjne formy pracy. Wydawnictwo EXPOL, Olsztyn. Oslo Manual Guidelines for Collecting, Reporting and Using Data on Innovation (3 ${ }^{\text {rd }}$ ed.). (2005). OECD: European Union.

Oslo Manual Guidelines for Collecting, Reporting and Using Data on Innovation (4 ${ }^{\text {th }}$ ed.). (2018). OECD: European Union. 
Pawlak, K., \& Poczta, W. (2011). Międzynarodowy handel rolny teorie konkurencyjność scenariusze rozwoju. Warszawa: Wydawnictwo Naukowe PWE.

Porter, M. E. (2001). Porter o konkurencji. Warszawa: Wydawnictwo Naukowe PWE.

Poznańska, K. (2001). Innowacyjność jako czynnik determinujący wzrost konkurencyjności małych i średnich przedsiębiorstw. In Materiały konferencyjne: Przedsiębiorstwo na przełomie wieków. Toruń.

Sieradzka, K., Luft, R., \& Walasik, M. (2015). Czynniki konkurencyjności przedsiębiorstw sektora turystycznego w Polsce. Logistyka, 4, 5634-5640.

Sita korelacji - klasyfikacja. (n.d.). Retrieved from http://www.naukowiec.org/wiedza/statystyka/sila-korelacji-klasyfikacja_512.html

Skawińska, E. (Ed.). (2002). Konkurencyjność przedsiębiorstw - nowe podejście. Warszawa: Wydawnictwo PWN.

Stownik wyrazów obcych. (1980). Warszawa: Wydawnictwo Naukowe PWN.

Stabryła, A., \& Małkus, T. (Eds.). (2012). Strategie rozwoju organizacji. Kraków: Wyd. Fundacja Uniwersytetu Ekonomicznego w Krakowie.

Stanisz, A. (2006). Przystępny kurs statystyki z zastosowaniem Statistica PL na przykladach z medycyny. Kraków: Wydawnictwo StatSoft.

Stankiewicz, M. J. (2002). Konkurencyjność przedsiębiorstwa. przedsiębiorstwa w warunkach globalizacji. Toruń: Wydawnictwo TNOiK.

Stankiewicz, M. J. (2005). Konkurencyjność przedsiębiorstwa. Budowanie konkurencyjności przedsiębiorstwa w warunkach globalizacji. Toruń: Wydawnictwo TNOiK.

Stieglitz, N., \& Heine, K. (2007). Innovations and the role of complementarities in a strategic theory of the firm. Strategic Management Journal, 28, 1-15. https://doi.org/10.1002/smj.565

Sundbo, J. (2001). The strategic management of innovation. UK: Edward Elgar Publishing Limited.

Świtalski, W. (2005). Innowacje i konkurencyjność. Warszawa: Wydawnictwo Uniwersytetu Warszawskiego.

Szreder, M. (2004). Metody i techniki sondażowych badań opinii. Warszawa: Wydawnictwo Naukowe PWE.

Szwacka-Mokrzycka, J. (2017). Czynniki konkurencyjności przedsiębiorstw przemysłu spożywczego w Polsce. Studia ekonomiczne. Zeszyty naukowe Uniwersytetu Ekonomicznego w Katowicach, 330, 205-213.

Volberda, H. W. (2000). Building the flexible firm. How to remain competitive. New York Oxford University Press inc.

Walczak, W. (2009). Niematerialne determinanty konkurencyjności współczesnych przedsiębiorstw. In S. Lachiewicz \& M. Matejun (Eds.), Konkurencyjność jako determinanta rozwoju przedsiębiorstwa (pp. 112-119). Lodź: Wydawnictwo Politechniki Łódzkiej.

Walczak, W. (2010). Analiza czynników wpływających na konkurencyjność przedsiębiorstw. E-mentor, 5(37), 5-12. Retrieved from http://www.academia.edu/9582321/Analiza_czynnik\%C3\%B3w_wp $\%$ C5\%82ywaj\%C4\%85cych_na_konkurencyjno $\% \mathrm{C} 5 \%$ 9B\%C4\%87_przedsi\%C4\%99biorstw

Zorska, A. (1998). Strategie korporacji transnarodowych w Polsce. Przeglad Organizacji, 2, 14-17. 